RFLP Report

\title{
DINUCLEOTIDE REPEAT POLYMORPHISM IN 65k-GLUTAMATE DECARBOXYLASE GENE*
}

\author{
Shigeo KURE,** Yoko AoKI, Toshikatsu SHINKA, Yoshiyuki SAKATA, \\ Yoichi MATSUBARA, and Kuniaki NARISAWA \\ Department of Biochemical Genetics, Tohoku University School of Medicine, \\ Seiryo-machi, Aoba-ku, Sendai 980-77, Japan
}

Key Words 65k-glutamate decarboxylase gene, microsatellite, EMBL3 genomic library, population study

65k-Glutamic acid decarboxylase (GAD65), $\gamma$-amino butyric acid synthesizing enzyme, plays a role not only in regulation of inhibitory neurotransmission, but also in pathogenesis of insulin-dependent diabetes mellitus and Stiffman's syndrome (Baekkeskov et al., 1990). The GAD65 gene is located in chromosome 10p11.23 (Bu et al., 1992). To facilitate the genetic studies of the GAD65 related disorders, we identified a polymorphic CA repeat marker in the GAD65 gene. A human genomic EMBL3 clone encoding the GAD65 gene was isolated and a CA repeat region was identified in the intron 15 (Kure et al., 1994). The repeat number of the CA was highly polymorphic, suggesting the usefulness of this genetic marker. A $(\mathrm{CT})_{7}(\mathrm{CA})_{\mathrm{n}}$ compound dinucleotide repeat was previously reported in the other region of the GAD65 gene (Wapelhorst et al., 1995). Those two polymorphic markers may provide the useful tools for studying the GAD65 related disorders.

$P C R$ primers

HGAD62 (CA primer): 5'GTATCATGTCCAGGAACCAG3'

HGAD53 (GT primer): 5'FAM-ACTGGACAGCATAGATTATTTCACC $3^{\prime}$ Polymorphism and frequency

Thirteen alleles were detected in 508 chromosomes of unrelated Japanese individuals and the observed heterozygosity frequency was 0.71 .

Received April 9, 1997; Revised version accepted June 3, 1997.

* A part of this work was presented in an abstract form of 44th Annual Meeting of The

American Society of Human Genetics (Am J Hum Genet 55, A156, 1994).

** To whom correspondence should be addressed. 


$\begin{array}{lll}\text { Allele } & \text { Size }(\mathrm{bp}) & \text { Frequency } \\ \text { A1 } & 128 & 0.03 \\ \text { A2 } & 130 & 0.53 \\ \text { A3 } & 132 & 0.04 \\ \text { A4 } & 134 & 0.02 \\ \text { A5 } & 136 & 0.01 \\ \text { A6 } & 138 & 0.01 \\ \text { A7 } & 140 & 0.06 \\ \text { A8 } & 142 & 0.17 \\ \text { A9 } & 144 & 0.04 \\ \text { A10 } & 146 & 0.05 \\ \text { A11 } & 148 & 0.01 \\ \text { A12 } & 150 & 0.02 \\ \text { A13 } & 152 & 0.01\end{array}$

Chromosomal localization. The GAD65 gene has been assigned to chromosome 10p11.23 (Bu et al., 1992).

Mendelian inheritance. Codominant inheritance was observed in two families.

Other comments. We screened the EMBL3 human genomic library with a GAD65 cDNA fragment and identified a CA repeat region by probing with $(C A)_{15}$ oligonucleotide. Sequencing analysis disclosed the franking sequences of the repeat region and a search of Genebank revealed no matching sequences. To elucidate the polymorphic profile of the CA repeat region, the regions of many individuals were amplified by PCR and the length of each PCR product was determined. The PCR reaction was carried out in a volume of $15 \mu \mathrm{l}$ containing 10 ng genomic DNA, 2.5 pmol of PCR primers, $200 \mu \mathrm{M} \mathrm{dNTP,} 1.5 \mathrm{mM} \mathrm{MgCl}_{2}, 50 \mathrm{mM}$ $\mathrm{KCl}, 0.001 \%$ gelatin, $10 \mathrm{~mm}$ Tris $\cdot \mathrm{HCl}(\mathrm{pH} 8.4)$, and $1 \mathrm{U}$ Taq polymerase (Amersham, Little Chalfon, England) in a 96-well type thermal cycler (PCR9600, Perkin-Elmer Corp. Norwalk, Conn., USA). Each thermocycle consisted of $94^{\circ} \mathrm{C}$ for $8 \mathrm{sec}, 55^{\circ} \mathrm{C}$ for $1 \mathrm{sec}$, and $72^{\circ} \mathrm{C}$ for $10 \mathrm{sec}$, and was repeated for 32 cycles. The forward primer was labelled with a fluorescence dye, FAM (Perkin-Elmer Corp.) to measure the length of the PCR products in the automated fluorescence DNA sequencer (A.L.F. Sequencer, Pharmacia, Uppsala, Sweden).

Acknowledgments This work was supported by a grant from the Ministry of Education, Science, Sports and Culture and the Ministry of Health and Public Welfare of Japan.

\section{REFERENCES}

Baekkeskov S, Aanstoot H-J, Christgau S, Reetz A, Solimena M, Cascalho M, Folli F, RichterOlesen H, Camilli P-D (1990): Identification of the 64K autoantigen in insulin-dependent 
diabetes as the GABA-synthesizing enzyme glutamic acid decarboxylase. Nature 347: 151156

Bu DF, Erlander MG, Hitz BC, Tillakaratne NJ, Kaufman DL, Wagner-McPherson CB, Evans GA, Tobin AJ (1992): Two human glutamate decarboxylases, $65-\mathrm{kDa}$ GAD and $67-\mathrm{kDa}$ GAD, are each encoded by a single gene. Proc Natl Acad Sci USA 89: 2115-2119

Kure S, Aoki Y, Tsuji I, Satoh J, Toyota T, Owada M, Kawamura T, Isshiki G, Narisawa K (1994): Association between a polymorphism of the $65 \mathrm{~K}$-glutamate decarboxylase gene and insulin-dependent diabetes mellitus. Am J Hum Genet 55: A156

Wapelhorst B, Bell GI, Risch N, Spielman RS, Concannon P (1995): Linkage and association studies in insulin-dependent diabetes with a new dinucleotide repeat polymorphism at GAD65 locus. Autoimmunity 21: $127-130$

Vol. 42, No. 3, 1997 